\title{
Online learning in the post-Covid-19 pandemic era: Is our higher education ready for it?
}

\section{${ }^{* 1}$ Hasan Djidu, ${ }^{1}$ Sufri Mashuri, ${ }^{1}$ Nasruddin, ${ }^{1}$ Andri Estining Sejati, ${ }^{2}$ Rasmuin, ${ }^{2}$ La Eru Ugi, ${ }^{3}$ Afudin La Arua}

\author{
${ }^{1}$ Faculty of Teachers Training and Education, Universitas Sembilanbelas November Kolaka, Jl. \\ Pemuda, Tahoa, Kolaka, Sulawesi Tenggara 93561, Indonesia \\ ${ }^{2}$ Mathematics Education Department, Universitas Dayanu Ikhsanuddin, Jl. Yos Sudarso No. 43, Kota \\ Bau-Bau, Sulawesi Tenggara 93711, Indonesia \\ ${ }^{3}$ Mathematics Department, Universitas Muslim Buton, Jl. Betoambari No.146, Kota Bau-Bau, Sulawesi \\ Tenggara 93721, Indonesia \\ *Corresponding Author e-mail: hasandjidu@gmail.com
}

Received: June 2021; Revised: July 2021; Published: July 2021

\begin{abstract}
This study aimed to describe the challenges of higher education in implementing online learning during the pandemic Covid-19 outbreak. This study was a qualitative research with a phenomenological approach. Data were collected from 408 students and 20 Lectures from 6 public universities and 6 private universities in Java, Sumatera, Kalimantan, Sulawesi, Nusa Tenggara, and Maluku, by filling out online questionaires and in-depth interviews via social media. The process of data analysis was data reduction, identifying themes, mapping interrelationships between themes, and concluding findings The results of data analysis showed that there were two main challenges, both for lecturers and students. First, limited resources, such as electronic devices (laptops/smartphones/others), learning resources, electricity, and internet connections. Second, lack of knowledge/skills on how to use the online learning media, finding and/or providing learning resources, managing online learning, providing online measuring tools, and carrying out online assessments. This condition has the greatest impact on students from low economic families, and who live in areas with limited access to learning facilities, such as electricity, and internet connections. Most of them lose learning opportunities because of these limitations. Third, the difficulty of time management during the online learning period.
\end{abstract}

Keywords: online learning, Covid-19 outbreak, pandemic, higher education

How to Cite: Djidu, H., Mashuri, S., Nasruddin, N., Sejati, A. E., Rasmuin, R., Ugi, L. E., \& Arua, A. L. (2021). Online learning in the post-Covid-19 pandemic era: Is our higher education ready for it?. Jurnal Penelitian Dan Pengkajian Ilmu Pendidikan: E-Saintika, 5(2), 139-151. https://doi.org/10.36312/esaintika.v5i2.479

\section{INTRODUCTION}

The Covid-19 outbreak has shocked the whole world. Spreading very quickly forced many countries to quarantine/ lockdown their territory, in part or in whole. Such restrictions lead to paralysis of various public activities, such as economy, public transport, public services, tourism, including education (Arora \& Srinivasan, 2020). Statistics from UNESCO (25/03/2020) mentioned that 1,524,648,768 students were affected by the covid-19 virus from $87.1 \%$ of the total students enrolled. India and 
China have the largest number of students affected by the Covid-19, which is more than 270 million students, and in Indonesia per Wednesday (25/3/2021) as many as $68,265,787$ students affected by Covid-19 (UNESCO, 2021). In Indonesia, the Covid-19 pandemic has been declared as a non-natural national disaster on March 16, 2020. The spread of Covid-19 in Indonesia until March 2021 has reached 1 million confirmed cases. Covid-19 infection has also spread in all provinces in Indonesia.

The Indonesian government was forced to cancel an important agenda, to anticipate the spread of the virus increasingly widespread and uncontrollable. The government also made a prohibition and restriction policy for the people to carry out activities that cause a crowd of people, ranging from social activities, religious activities, or other activities that increase the risk of transmission. Social and physical distancing, as well as awareness for self-quarantine at home continued to be campaigned by the government to break the chain of the spread of this virus.

The most significant effect due to the Covid-19 outbreak for education was the loss of classroom learning activities as usual (Liguori \& Winkler, 2020; Lynch, 2020; Zhang, Wang, \& Yang, 2020). Schools, training and career centers, including higher education institutions are forced to be closed, students must study at home totally, no scientific meetings or discussions at schools, no face-to-face meeting between teachers/lecturers and students (Adedoyin \& Soykan, 2020; Arora \& Srinivasan, 2020; Crawford et al., 2020; Halil, 2020; Hodges, Moore, Lockee, Trust, \& Bond, 2020; Laloo \& Kharkongor, 2020; Lynch, 2020; Simamora, 2020; Smalley, 2020; Toquero, 2020). Suddenly, everything must change quickly because of the Covid-19 outbreak (Crawford et al., 2020; Hodges et al., 2020). Most recently, the National Education Standards Agency of the Republic of Indonesia, as the authorized party in the implementation of the National Examination (NE), canceled the last NE in 2020 for secondary schools, which was an effort against the spread of the Covid-19 outbreak. This NE is planned to be the last since the policy was changed by NE with Asesmen Kompetensi Minimum (AKM) and character surveys (Retnawati et al., 2019).

In order to maintain the sustainability of education, the Ministry of Education and Culture (Kemendikbud) of the Republic of Indonesia urges all educational institutions to switch face-to-face learning in class to online learning. In fact, the readiness of educational institutions in implementing online learning has never been evaluated. As a result, the challenges and problems that may be faced by educational institutions in implementing online learning have not been revealed (Chung, Noor, \& Vloreen Nity Mathew, 2020; Tereseviciene, Trepule, Dauksiene, Tamoliune, \& Costa, 2020).

Changes in the implementation of the education system around the world today are indeed different from normal conditions (Supariani, Rinda, Herlianti, \& Djidu, 2021). Everyone is forced to be able to use technology suddenly without any preparation. In Indonesia itself, the transition to using technology in the implementation of education, especially assessments (National Examination) has been carried out since 2015 (Retnawati, Hadi, et al., 2017). The challenges faced today are slightly different from what happened during the transition from pencil-paper-based national exams, became a computer-based national exam at that time. The transition carried out at that time was carried out in stages, starting with a study, and adjusting to the conditions of school readiness. However, the implementation of the NE still faces many obstacles, as reported in the study conducted by Retnawati et al. (2017). 
Today, the national emergency situation forces all educational institutions to take online learning alternatives, although with various limitations.

In the last two decades, education in Indonesia has been reformed with 21st Century competency-oriented learning. Creating a learning atmosphere in both schools and higher education that develops thinking skills has been pursued for two decades (Djidu \& Jailani, 2016; Jailani, Heri Retnawati, Wulandari, \& Djidu, 2020; Yuliani, 2014). Various learning models and method that support the development of thinking skills are also intensively introduced, such as problem-based learning (Djidu \& Jailani, 2018; Kurniawan \& Djidu, 2021), project-based learning (Anazifa \& Djukri, 2017; Chen \& Yang, 2019), and scaffolding method . However, the results of the study show that until the last 3 years there are still many teachers who have difficulty implementing it (Retnawati, 2015; Retnawati, Arlinwibowo, Wulandari, \& Pradani, 2018; Retnawati, Djidu, Kartianom, Apino, \& Anazifa, 2018; Retnawati, Munadi, Arlinwibowo, Wulandari, \& Sulistyaningsih, 2017), even though it has been implemented for more than two decades.

Several higher education institutions have indeed built a Learning Management System (LMS) and implemented the Blended Learning (BL) learning model for the past few years (Joubert, Callaghan, \& Engelbrecht, 2020; Owston, 2013). BL is implemented by combining face-to-face learning activities in class, and online learning (Kaur, 2013; Nazarenko, 2015). However, what would happen if learning now had to be carried out $100 \%$ online, without face-to-face?. The question of how practicum activities can be carried out with online learning, whether higher education institutions are ready to implement it, and whether students are also ready to take part in this online learning, are still big questions for us. Therefore, this study will describe the challenges of higher education in conducting online learning during the Covid-19 pandemic.

This study aims to answer two questions, namely (1) how do universities implement online learning during the covid-19 pandemic?, and (2) what are the challenges faced by higher education in implementing online learning during the Covid-19 pandemic? We hope that the results of this study will become one of the considerations for higher education institutions and the government in making policies to improve the quality and equity of education today and in the postpandemic period.

\section{METHOD}

\section{Research Design}

It is noticeable that the research objectives are aimed to explore people's views and social behaviour. The philosophy of interpretivism focuses on people behavior and endeavors to explain it (Bryman, 2012). Taking this fact into account it seems logical to adopt the interpretivist perspective, which is connected to the qualitative research strategy. This study was a phenomenology qualitative research. The focus of this research is to describe the challenge of higher education in implementing online learning during the pandemic Covid-19 Outbreak in Indonesia.

\section{Participants and Data Collection}

Participants in this study were lecturers and students from 12 universities from western to eastern Indonesia (6 public universities and 6 private universities), with ratings of Unggul (Excelent), Baik Sekali (Very Good), and Baik (Good). 20 lecturers and 
408 students responded to an online questionnaire (http://bit.ly/kendalapembelajarandaring) related to the challenges in implementing online learning during the Covid-19 pandemic (see Figure 1). During this process, the research explained that the data was only used for research purposes and that all the identities of the respondents were not displayed. The questionnaire procedures neither affected the teachers' career nor anything else, only used as a research purpose.

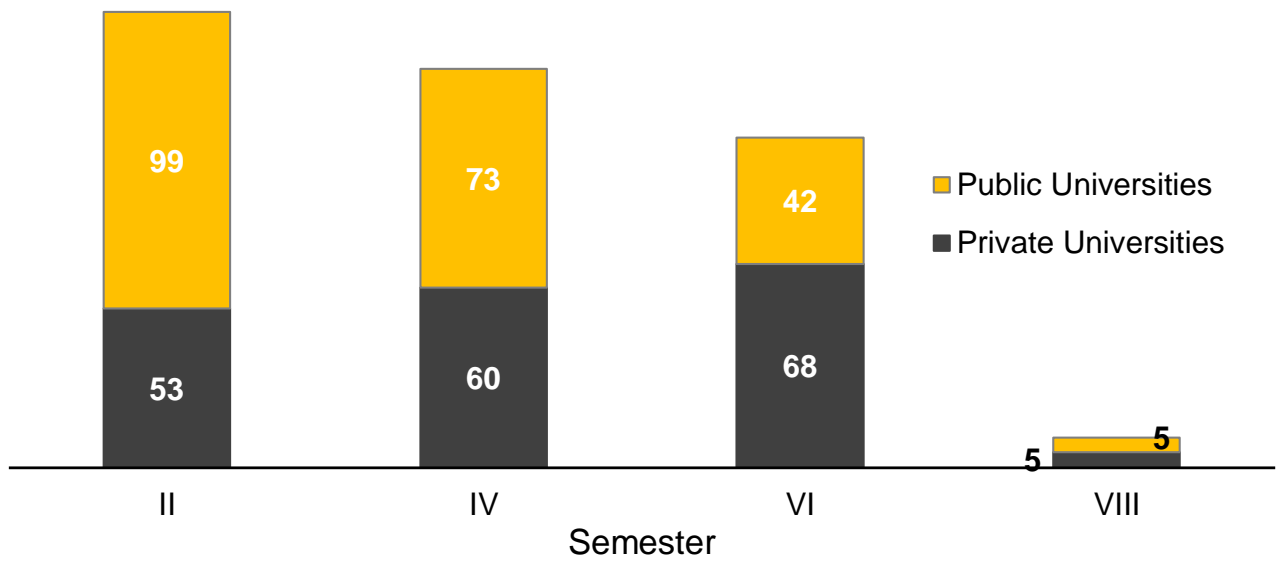

Figure 1. Respondents (Students)

\section{Data Analysis}

The data were analyzed using two approaches, namely descriptive quantitative and qualitative. Data related to the number and types of learning methods were analyzed using a quantitative descriptive approach, then the results were presented in the form of a diagram. Meanwhile, qualitative data derived from the responses of students and lecturers regarding the challenges faced were analyzed using a qualitative approach. Their responses to open questionnaires, as well as interviews were recorded and reduced to obtain themes related to the challenges faced. The process of data analysis was data reduction, identifying themes, mapping interrelationships between themes, and concluding findings. This approach is adapted from Bogdan \& Biklen (2007).

\section{Ethical Considerations}

In this study, the only relationship between researchers and participants is to obtain data related to challenges to implement online learning in Covid-19 pandemic era. All data collected in this study only sourced from the responses of 15 lecture and 408 students who participated in this study. Furthermore, the identities of all participants were anonymized and written with code: L1, L2, L3, ... (for lectures), and S1, S2, S3, ... (for students). Each Lecture's response was recorded and inputted in a table to be analyzed and described. Some of the Lecture's responses that can provide a general description of a phenomenon are selected and presented as examples in this article so L1 - L15 or S1 - S408 is not mentioned entirely in this article.

\section{RESULTS AND DISCUSSION}

The data that has been collected using an online questionnaire has been analyzed and grouped into 2 (two) sub-sections to answer the questions of this study. First, to answer the question how do universities implement online learning during the Covid19 pandemic, we collect data related to the learning method that most frequently used during the Covid-19 pandemic. Second, to answer the question what are the challenges faced by higher education in implementing online learning during the 
covid-19 pandemic, we collect data related to the challenges faced by lecture and students during online learning. The results of data analysis lead us to the answers to these two questions, as described below.

\section{Learning Method during Covid-19 Pandemic}

This subsection aims to answer the question- 1 how do universities implement online learning during the covid-19 pandemic. We asked students about what media/learning methods were most often followed during the covid-19 pandemic. In this section, it is revealed how the learning process has been implemented in a number of higher education institutions in Indonesia, (in this context 12 higher education institutions participated in this study).

The results of data analysis (see Figure 2) show that most of the learning activities carried out using the a-syncronize method utilize social media. With a total of 101 responses, this learning method is more widely used than the Learning Management System (LMS) which only reached 86 responses, and learning using video conferencing media (77 responses). This condition is relevant to a number of challenges faced by both lecturers and students in implementing learning using LMS.

Attending online class via social media

Uploading assigment via LMS

Attending online class via video conference

Sending assigment via e-mail

Watching online lecture from an expert/tutor

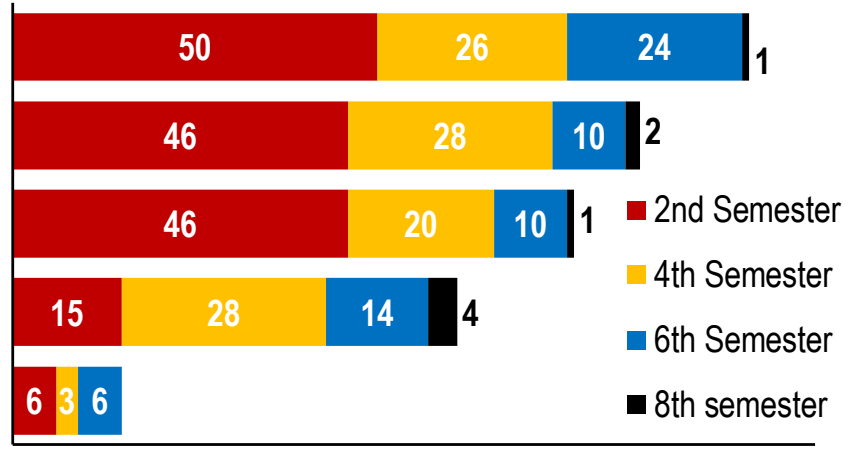

$\begin{array}{llllllllllll}0 & 10 & 20 & 30 & 40 & 50 & 60 & 70 & 80 & 90 & 100 & 110\end{array}$

Figure 2. The most frequent learning methods (students' responses)

Learning through social media is carried out by creating groups or channels on social media. These groups and channels are used by lecturers to send learning resources for students such as textbooks, text messages, audio messages, and videos. The rules for implementing learning, sending assignments, including exam questions, are conveyed by the lecturer through social media. Furthermore, learning with asynchronize mode is also carried out using LMS and e-mail.

Compared to social media, unfortunately, LMS is still not widely used. There are two reasons why LMS is not more widely used than social media in its use. There are still many higher education institution that have not developed LMS to support the implementation of learning. In addition, online learning was still unfamiliar among lecturers and students before the COVID-19 pandemic. As a result, the suspension of face-to-face in class causes confusion for lecturers and students in carrying out learning. The following are examples of statements made by lecturers and students.

"We've never done online learning before ... if going to class is prohibited, how are we supposed to teach?" [L-2]

"This is the first time we have participated in online learning activities ... we've never studied using this method before" [S-17] 
Second, there are still many lecturers who have not been able to use LMS properly. As a result, the LMS that has been provided by the institution is not used in carrying out learning. This means that some LMS that have been developed by higher education institutions have not been fully utilized, instead of using them, lecturers still choose to implement conventionally (face-to-face learning in class). This condition is related to the challenges faced by these lecturers in utilizing the LMS itself (discussed in the next section).

Meanwhile, synchronous learning, using learning platforms such as Zoom, Google Meet, was only carried out by 77 out of 408 students. These two platforms provide facilities for conducting online meetings and facilitate new categories for most lecturers and students. This condition is also caused by a number of challenges in its implementation, both technical and non-technical problems.

\section{The challenges of higher education implementing online learning}

In this second section, the challenges faced by lecturers and students in the implementation of online learning are described. These challenges have a correlation with the selection of online learning implementation methods, as explained in the previous sub-chapter. The problems that were revealed, some of which are not new problems, but have been revealed for a long time and have only recently been revealed.

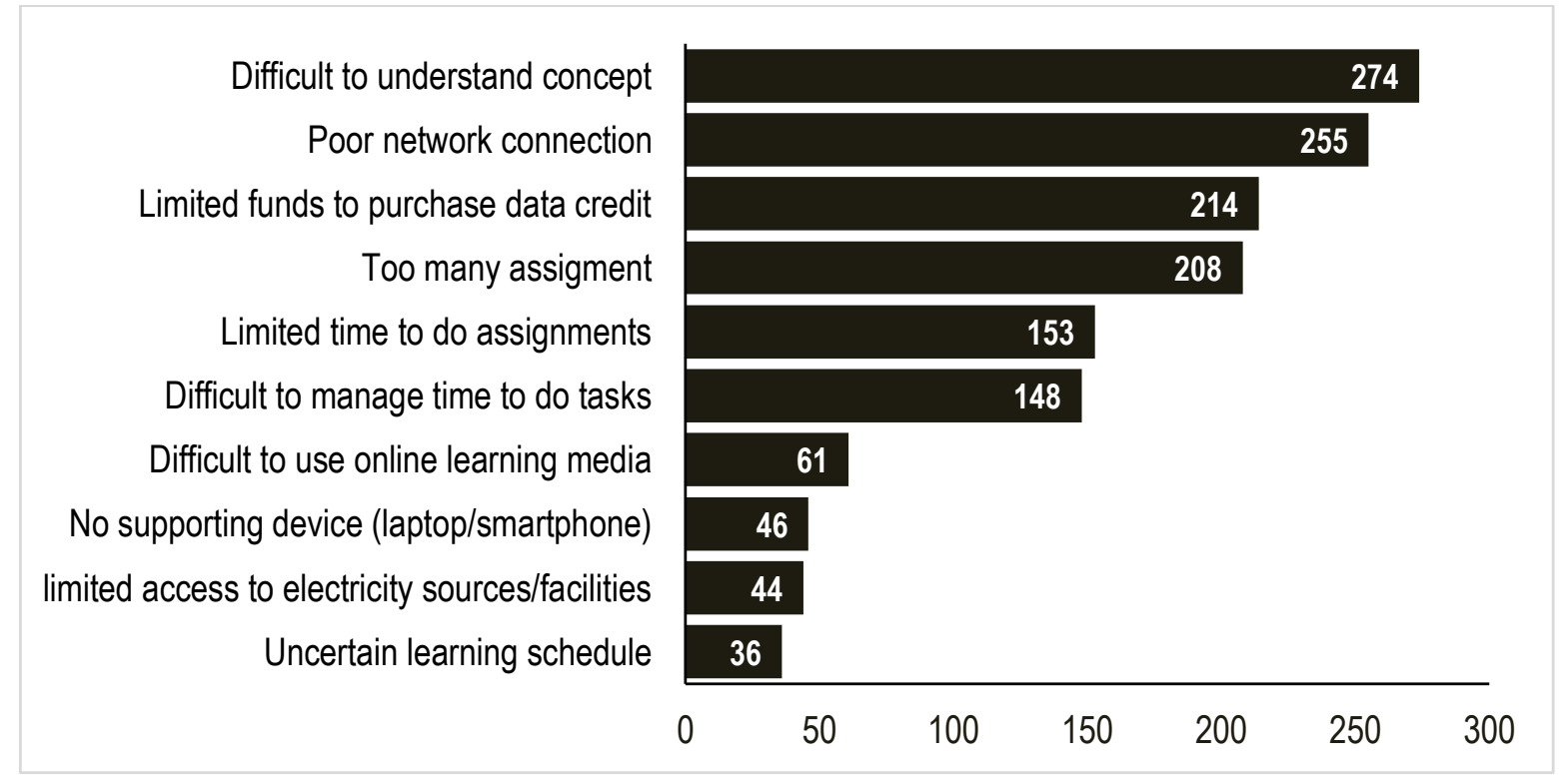

Figure 3. Challenges during online learning

Lecturer and student response data, obtained several themes related to challenges during online learning. After data reduction, we found the 10 most common challenges faced by them (see Figure 3). From these challenges, three main themes of online learning challenges were obtained.

First, limited facility resources, such as electronic devices (laptops/ smartphones/ others), learning resources, electricity, and internet connections. Second, lack of knowledge/skills on how to use online learning media, find and/or provide learning resources, manage online learning, provide online measuring tools, and carry out online assessments. Third, challenges related to time management. 


\section{Limited facility resources}

Online learning requires the support of facilities to be effective. Unfortunately, not all regions in Indonesia have facilities for online learning. There are still many areas in our country which, in fact, are isolated from the outside world, without access to electricity. Many students have to climb to the top of a hill/mountain, roadside, or climb a tree to get an internet connection. Indeed, internet connection problems can be solved with this, but it is not a guarantee that they can attend the learning process well. Then, what about those who don't even have access to electricity?

"In my village, there is no electricity... Then, how do we find internet connection? ... during this pandemic, we find it difficult to learn" [S-33]

"I have lost contact with some of my students since face-to-face learning in class was discontinued" [L-1]

In addition, the implementation of online learning is still dominated by the use of social media, rather than using LMS. This is due to the unavailability of online learning platforms at these higher education institutions.

"We don't have our own server support to develop LMS in our institution... The only way is to use social media, because it is well known and used by students almost every day" [L3]

Efforts to get an internet connection actually only solve problems related to student participation in the learning process. But what about the quality of the learning they get? In fact, most say they have difficulty understanding the concepts that are the topic of learning.

"It's so hard to study online... lots of subject matter is hard to understand" [S-6]

"Our lecturer's voice is sometimes not heard by us... a lot of information that we can't hear well" [S-21]

Another problem faced by students with low family economic income. Usually, under normal conditions they can access the internet easily and for free through the facilities provided by the university. Now, when access to universities is restricted, students have to spend money to pay for the internet connection fees needed during the learning process. Those with low economic income are unable to purchase credit to be able to access the internet. They don't even have the facilities to participate in online learning (e.g. smartphones, laptops, and other supporting devices). As a result, some of them are not able to follow the lesson at all.

Not only students, higher education institutions also face problems that hinder online learning, one of which is the absence of an integrated Learning Management System (LMS). Lecturers are forced to seek independent media to carry out online learning. As discussed above, most of the lectures are carried out using only social media due to the absence of an LMS. As a result, the quality control of the implementation of online learning is not optimal.

"We don't have our own server support to develop LMS in our institution" [L-3] 
The most mentioned cause related to the absence of LMS from higher education institutions is server capacity that is not supported/sufficient. The need for this server is very urgent to be owned by a large institution such as a university because they manage thousands, even tens of thousands of student data. Likewise, to support the needs of online learning during this pandemic.

\section{Lack of knowledge/skills on how to use online learning media}

The second challenge is the lack of knowledge (lecturers and students) about how to use/operate various online learning media. Those who are accustomed to conventional learning (face to face) in the classroom must strive to use/operate various online learning media. Their resistance to online learning innovations has to deal with pandemic conditions that force everyone to be able to use online learning media.

"So far, I have been lazy to update my knowledge regarding web-based learning media innovations or the like... now I have to learn to use them" [L-10]

\section{"I have never tried to teach using video" [L-7]}

Another challenge is the availability of online-based learning resources. Usually, textbooks are the main choice, compared to online-based reference sources, current research results, or other references available online. Students and lecturers still face difficulties in finding these online learning resources. The inability to use online learning media has resulted in learning management that cannot run optimally. The assignment method, in the end, became the main choice by most lecturers. Social media is a medium for delivering assignments, sometimes references, while students must study independently from home. On the other hand, low English proficiency makes it difficult for students to study electronic text books, which are mostly in English. Meanwhile, the Indonesian language text books which they usually read in the library are not yet available electronically.

In addition, the lack of knowledge of some lecturers regarding online-based assessment techniques exacerbates the learning crisis. 7 out of 15 lecturers stated that they still did not have the knowledge and experience to carry out online assessments. The most common obstacle was the difficulty of monitoring students in taking tests. Many students still do plagiarism in doing assignments so it is difficult to get valid information regarding their performance. Not only knowledge assessment, attitude and character assessment is also very difficult to carry out during online learning.

"It's difficult to assess student performance... I find many students 'nyontek' (cheating) on their friends' work when doing assignments" [L-5]

\section{"I find it difficult to assess student attitudes/characters through online learning" [L-9]}

\section{Challenges related to time management.}

The use of the assignment method by almost all lecturers has an impact on students. Many of them complain that they find it difficult to manage their time due to too many assignments in one time period. In addition, the implementation of learning does not always follow a predetermined schedule. Often they receive assignments from lecturers not on schedule. 
"Almost all lecturers give a lot of assignments (not as usual) ... I am confused, which one should I finish first." [S-10]

Online learning time management is also faced with poor internet connection, and the absence of supporting tools. These challenges have made online learning ineffective.

"Some lecture sessions had to be rescheduled because at the time the internet connection was not good" [L-7]

Switching face-to-face learning in class to online learning is not easy. At least, there are four main aspects that must be prepared to effectively organize full online learning, namely, learning resources, software support, infrastructure, and regulations (Chung et al., 2020; Joosten \& Cusatis, 2020; Zhang et al., 2020; Zulkifli, Hamzah, \& Bashah, 2020). After these four aspects are met, skills/knowledge/readiness are still needed to manage online learning (Basilaia, Dgebuadze, \& Kantaria, 2020; Chung et al., 2020; Joosten \& Cusatis, 2020; Lynch, 2020; Zulkifli et al., 2020).

Learning resources that were previously presented in print, whether accessed through the library or in the classroom, are no longer accessible. Students who do not have their own learning resources in print can no longer access the library because library services have been restricted during the pandemic. On the other hand, most of the electronic books (e-books) available are in English. The lack of English proficiency of students' has become another new problem that must be faced by students.

The characteristics of the courses have become crucial in this online learning period. Learning materials that are theoretical in nature and aim to develop the ability to master concepts and understanding can still be sent online. However, the learning material, which is aimed at developing skills, becomes very difficult. Students who are supposed to practice their skills (e.g. in the laboratory, studio or classroom) cannot be replaced online. In addition, the delivery of lecture materials that require direct demonstrations is still not running well. To overcome difficulties in delivering material that requires demonstration, lecturers must provide learning resources in the form of videos, or conduct online lectures that are synchronized classes using various applications, such as Zoom, Google Meet, Facebook Messenger, Big Blue Button, or other services. Unfortunately, synchronized online learning cannot run well due to the limitations of supporting infrastructure, starting from the network, the availability of internet connections, and even some areas are still constrained by the unavailability of electricity connections.

Although there are many challenges, it turns out that online learning also has a positive side. One of them is that students are more active in asking / answering questions during the learning process. There is a tendency that they do not hesitate to express their opinions or questions during online learning compared to direct learning (face to face in class).

"My students are more active in asking/giving arguments in online learning than face-toface learning in class" [L-5]

This pandemic has served as an effective catalyst to expand educational opportunities particularly with respect to knowledge sharing through various 
technology. However, efforts to develop student skills are still not optimal through online learning so far (Stambough et al., 2020).

COVID-19 crisis sheds light on the need for a new education model. With the conditions described above, it seems that our higher education is still not ready for online learning in the post-pandemic era. There are still many improvements that are needed and of course must be supported by policies from the government. After dealing with this pandemic for more than a year, lecturers and students will be more familiar with various learning technologies in the future.

\section{CONCLUSION}

Online learning carried out in higher education during the Covid-19 pandemic still faces many challenges, which results in hampering student learning activities. There are three things that become a source of problems in implementing online learning. First, limited resources, such as electronic devices (laptops/smartphones/other), learning resources, electricity, and internet connections. Second, lack of experience, knowledge, and skills on how to use online learning media, difficulties in finding and/or providing learning resources, difficulties in managing online learning, and difficulties in providing measuring tools for carrying out online assessments. Third, the difficulty of time management during the online learning period.

\section{RECOMMENDATION}

The results of this study also show that various problems are faced by both lecturers and students, regardless of the grade of the institution. The availability of supporting resources that are indirectly related to the geographical location of the area of residence, and the economic conditions of students, as well as experience in managing and participating in online learning are some of the most common factors found in this study. However, this study does not specifically discuss the size of the influence of these factors quantitatively in the implementation of online learning. To find out more about the contribution of these factors in the implementation of online learning in higher education, further studies are still needed.

Finally, the COVID-19 outbreak has made everyone aware of the need to prepare supporting infrastructure for online learning, to face various challenges that may come in the future. All parties are also forced to try to learn and use various online learning media, which so far have never been tried or are indifferent to their development. Finally, we all hope that this pandemic will end soon so that the learning process can return to normal.

\section{ACKNOWLEDGMENT}

This research received no specific grant from any funding agency in the public, commercial, or not for profit sectors.

\section{REFERENCES}

Adedoyin, O. B., \& Soykan, E. (2020). Covid-19 pandemic and online learning: the challenges and opportunities. Interactive Learning Environments, 0(0), 1-13. https:/ / doi.org/10.1080/10494820.2020.1813180

Anazifa, R. D., \& Djukri. (2017). Project-based learning and problem-based learning: are they effective to improve student's thinking skills? Jurnal Pendidikan IPA Indonesia, 6(2), 346-355. https:/ / doi.org/10.15294/jpii.v6i2.11100 
Arora, A. K., \& Srinivasan, R. (2020). Impact of pandemic covid-19 on the teaching learning process: A study of higher education teachers. Prabandhan: Indian $\begin{array}{llll}\text { Journal of } & \text { 43-56. }\end{array}$ https://doi.org/10.17010/pijom/2020/v13i4/151825

Basilaia, G., Dgebuadze, M., \& Kantaria, M. (2020). Replacing the classic learning form at Universities as an immediate response to the COVID-19 Virus infection in Georgia. International Journal for Research in Applied Science $\mathcal{E}$ Engineering Technology (IJRASET), 8(3), 101-108.

Bogdan, R. C., \& Biklen, S. K. (2007). Naturalistic inquiry and the saturation concept: a research note. Qualitative Research, 8(1), 137-152. https://doi.org/10.1177/1468794107085301

Chen, C. H., \& Yang, Y. C. (2019). Revisiting the effects of project-based learning on students' academic achievement: A meta-analysis investigating moderators. Educational Research Review, Vol. 26, pp. 71-81. https://doi.org/10.1016/j.edurev.2018.11.001

Chung, E., Noor, N. M., \& Vloreen Nity Mathew. (2020). Are you ready? an assessment of online learning readiness among university students. International Journal of Academic Research in Progressive Education and Development, 9(1), 301-317. https:/ / doi.org/10.6007/IJARPED/v9-i1/7128

Crawford, J., Butler-Henderson, K., Rudolph, J., Malkawi, B., Glowatz, M., Burton, R., ... Lam, S. (2020). COVID-19: 20 countries' higher education intra-period digital pedagogy responses. Journal of Applied Learning $\mathcal{E}$ Teaching, 3(1). https://doi.org/10.37074/jalt.2020.3.1.7

Djidu, H., \& Jailani. (2016). Fostering student's higher-order thinking skill through problem-based learning in calculus. Proceeding of 3rd International Conference on Research, Implementation and Education of Mathematics and Science, 127-130. Yogyakarta: Faculty of Mathematics and Science-Yogyakarta State University. Retrieved from http://seminar.uny.ac.id/icriems/sites/seminar.uny.ac.id.icriems/files/prosi ding/ME-19.pdf

Djidu, H., \& Jailani, J. (2018). Developing problem based calculus learning model. Jurnal Kependidikan: Penelitian Inovasi Pembelajaran, 2(1), 68-84. https://doi.org/10.21831/jk.v2i1.12689

Halil, N. I. (2020). The effectiveness of using Edmodo as an online learning platform in Covid-19. Jurnal Penelitian Dan Pengkajian Ilmu Pendidikan: E-Saintika, 4(3), 284. https://doi.org/10.36312/e-saintika.v4i3.316

Hodges, C., Moore, S., Lockee, B., Trust, T., \& Bond, A. (2020). The Difference Between Emergency Remote Teaching and Online Learning. Educause, 1-12. Retrieved from https://er.educause.edu/articles/2020/3/the-difference-betweenemergency-remote-teaching-and-

Jailani, J., Heri Retnawati, H. R., Wulandari, N. F., \& Djidu, H. (2020). Mathematical literacy proficiency development based on content, context, and process. Problems of Education in the 21st Century, 78(1), 80-101. https://doi.org/10.33225/pec/20.78.80

Joosten, T., \& Cusatis, R. (2020). Online learning readiness. American Journal of Distance Education, 34(3), 180-193. https:/ / doi.org/10.1080/08923647.2020.1726167

Joubert, J., Callaghan, R., \& Engelbrecht, J. (2020). Lesson study in a blended approach to support isolated teachers in teaching with technology. ZDM - Mathematics 
Education, 52(5), 907-925. https://doi.org/10.1007/s11858-020-01161-x

Kaur, M. (2013). Blended learning - its challenges and future. Procedia - Social and Behavioral Sciences, 93, 612-617. https://doi.org/10.1016/j.sbspro.2013.09.248

Kurniawan, R., \& Djidu, H. (2021). Kemampuan literasi matematis siswa: Sebuah studi literatur. EDUMATIC: Jurnal Pendidikan Matematika, 2(1), 24-30. Retrieved from

http://ejournal.stkippacitan.ac.id/index.php/edumatic/article/view/338

Laloo, I. W. J., \& Kharkongor, G. C. (2020). Teaching experiences of university faculty during the COVID-19 Pandemic: Content for teacher upskilling and perceptions on career progression. 9(1), 13-34.

Liguori, E., \& Winkler, C. (2020). From Offline to Online: Challenges and Opportunities for Entrepreneurship Education Following the COVID-19 Pandemic. Entrepreneurship Education and Pedagogy, 251512742091673. https://doi.org/10.1177/2515127420916738

Lynch, M. (2020). E-Learning during a global pandemic. Asian Journal of Distance Education, 15(1), 2020. Retrieved from http://www.asianjde.org

Nazarenko, A. L. (2015). Blended Learning vs Traditional Learning: What Works? (A Case Study Research). Procedia - Social and Behavioral Sciences, 200(October), 7782. https://doi.org/10.1016/j.sbspro.2015.08.018

Owston, R. (2013). Blended learning policy and implementation: Introduction to the special issue. Internet and Higher Education, 18, 1-3. https://doi.org/10.1016/j.iheduc.2013.03.002

Retnawati, H. (2015). Hambatan guru matematika sekolah menengah pertama dalam menerapkan kurikulum baru. Jurnal Cakrawala Pendidikan, 34(3), 390-403. https://doi.org/10.21831/cp.v3i3.7694

Retnawati, H., Arlinwibowo, J., Wulandari, N. F., \& Pradani, R. G. (2018). Teachers' difficulties and strategies in physics teaching and learning that applying mathematics. Journal of Baltic Science Education, 17(1), 120-135. Retrieved from http://www.scientiasocialis.lt/jbse/files/pdf/vol17/120-

135.Retnawati_JBSE_Vol.17_No.1.pdf

Retnawati, H., Djidu, H., Kartianom, K., Apino, E., \& Anazifa, R. D. (2018). Teachers' knowledge about higher-order thinking skills and its learning strategy. Problems of Education in the 21st Century, 76(2), 215-230. Retrieved from http:/ / oaji.net/articles/2017/457-1524597598.pdf

Retnawati, H., Hadi, S., Munadi, S., Hadiana, D., Muhardis, M., Apino, E., ... Rosyada, M. N. (2019). When national examination no longer determining graduation, will students accomplish it seriously? Indonesian Journal of Educational Assesment, 2(2), 40-49. https:// doi.org/10.26499/ijea.v2i2.34

Retnawati, H., Hadi, S., Nugraha, A. C., Arlinwibowo, J., Sulistyaningsih, E., Djidu, H., ... Iryanti, H. D. (2017). Implementing the computer-based national examination in Indonesian schools: The challenges and strategies. Problems of Education in the 21st Century, 75(6).

Retnawati, H., Munadi, S., Arlinwibowo, J., Wulandari, N. F., \& Sulistyaningsih, E. (2017). Teachers' difficulties in implementing thematic teaching and learning in elementary schools. The New Educational Review, 49(3), 201-212. https://doi.org/10.15804/tner.2017.48.2.16

Simamora, R. M. (2020). The challenges of online learning during the COVID-19 pandemic: An essay analysis of performing arts education students. Studies in 
Learning and Teaching, 1(2), 86-103.

Smalley, A. (2020). Higher education responses to Coronavirus (COVID-19). National Conference of State Legislatures, 1-17. Retrieved from https://www.ncsl.org/research/education/higher-education-responses-tocoronavirus-covid-19.aspx

Stambough, J. B., Curtin, B. M., Gililland, J. M., Guild, G. N., Kain, M. S., Karas, V., ... Moskal, J. T. (2020). The past, present, and future of orthopedic education: Lessons learned from the COVID-19 pandemic. The Journal of Arthroplasty, 35(7), S60-S64. https://doi.org/10.1016/j.arth.2020.04.032

Supariani, N. K. D., Rinda, R., Herlianti, R., \& Djidu, H. (2021). Kendala dalam pembelajaran daring. EDUMATIC: Jurnal Pendidikan Matematika, 2(1), 17-23. Retrieved from http://ejournal.stkippacitan.ac.id/index.php/edumatic/article/view/337

Tereseviciene, M., Trepule, E., Dauksiene, E., Tamoliune, G., \& Costa, N. (2020). Are universities ready to recognize open online learning? International Education Studies, 13(2), 21. https:/ / doi.org/10.5539/ies.v13n2p21

Toquero, C. M. (2020). challenges-and-opportunities-for-higher-education-amid-thecovid-19-pandemic-the-philippine-context. Pedagogical Research. https://doi.org/10.29333/pr/7947

UNESCO. (2021). Global tracking of COVID-19 caused school closures and re-openings Methodological Note. (January), 2021.

Yuliani, A. (2014). Efforts To Improve Students' Mathematical Literacy in Mathematics Learning. Proceeding of International Conference On Research, Implementation And Education Of Mathematics And Sciences 2014, (May), 99-104.

Zhang, W., Wang, Y., \& Yang, L. (2020). Suspending classes without stopping learning: China's education emergency management policy in the COVID-19 outbreak. Journal of Risk and Fiancial Management, 13(55), 1-6. https://doi.org/10.3390/jrfm13030055

Zulkifli, N., Hamzah, M. I., \& Bashah, N. H. (2020). Challenges to teaching and learning using MOOC. Creative Education, 11(03), 197-205. https://doi.org/10.4236/ce.2020.113014 